\title{
Kontrol Optimum pada Model Epidemik SIR dengan Pengaruh Vaksinasi dan Faktor Imigrasi
}

\author{
N. Anggriani, A. Supriatna, B. Subartini, R. Wulantini \\ Program Studi Matematika FMIPA Unpad \\ Jl. Raya Bandung - Sumedang km. 21 Jatinangor \\ Email: nursanti.anggriani@unpad.ac.id
}

\begin{abstract}
ABSTRAK
Pada artikel ini dibahas model imigrasi SIR (Susceptible-Infected-Recovered) dengan memberikan pengaruh vaksinasi. Diasumsikan vaksinasi diberikan kepada populasi pendatang dan bayi yang baru lahir, dengan tujuan untuk mengurangi penyebaran penyakit tersebut. Masalah kontrol optimal diselesaikan dengan menggunakan prinsip Maksimum Pontryagin dengan tujuan untuk meminimumkan jumlah individu terinfeksi. Simulasi numerik menunjukkan keefektifan pengendalian dengan kontrol pengobatan dan vaksinasi dapat mengurangi populasi yang terinfeksi sehingga penyebaran penyakit dapat dicegah.
\end{abstract}

Kata Kunci : Model SIR, Vaksinasi, Imigrasi, Kontrol Optimal.

\section{ABSTRACT}

This paper discusses an imigran SIR model with vaccination factor. We assumed that the vaccination given to the imigran population and the newborn baby to control the disease transmission. The Maximum Pontryagin Principle is used in the optimal control problem to minimize the number of infected people. Numerical simulation shows the effectiveness of treatment and vaccination control that can reduce the number of infected people, so the spread can be prevented.

Keywords : SIR Models, Vaccination, Immigration, Stability Analysis, Optimal Control.

\section{Pendahuluan}

Penyakit menular adalah masalah yang dihadapi hampir disemua negara tanpa memandang status. Penyakit menular diantaranya adalah campak, gondok, rubella, polio dan pertusis merupakan penyakit infeksi yang sangat berbahaya. Penyakit tersebut disebabkan oleh virus yang dapat menyebar melalui kontak langsung dengan penderita, udara, batuk, atau bersin dan kotoran manusia. Ada beberapa faktor epidemiologi dan demografi yang berkontribusi terhadap penularan penyakit. Faktor yang memainkan peran penting dalam penularan penyakit adalah imigrasi. Imigrasi individu yang terinfeksi dapat memicu penyebaran penyakit dalam populasi. Brauer [1] memperlihatkan bahwa jika terdapat populasi imigran yang terinfeksi masuk ke dalam suatu populasi secara konstan, maka tidak terdapat titik ekulibrium bebas penyakit pada sistem tersebut. Meskipun imigran tidak membawa penyakit sama sekali, tetap saja mereka berdampak pada penularan penyakit [1].

Semakin banyaknya imigran dan populasi penduduk setempat dapat juga mengakibatkan penambahan populasi manusia rentan (susceptible) yang dapat terinfeksi kembali jika terdapat manusia yang terinfeksi masuk kedalam populasi tersebut sehingga dapat menyebabkan penyebaran penyakit. Salah satu upaya untuk mencegah meluasnya penyakit tersebut adalah dengan melakukan program vaksinasi. Dalam hal ini, diperlukan suatu kebijakan dalam pemberian vaksinasi bagi imigran, dilanjutkan dengan melakukan screening, untuk memastikan bahwa mereka tidak akan berkontribusi pada pertambahan populasi yang rentan. Penyakit seperti HIV, SARS dan flu burung merupakan beberapa penyakit yang dapat menyebar disebabkan oleh faktor imigrasi [2,3] Selain kontribusi dari bidang kesehatan dalam mencegah menyebarnya penyakit menular, perkembangan ilmu pengetahuan dibidang lain seperti di bidang matematika juga turut memberikan peranan yang penting. Salah satunya berupa pemodelan matematika. 
Banyak model matematika yang sudah dibuat untuk mengkontrol penyebaran penyakit menular khususnya model yang memasukkan faktor imigrasi [4,1]. Piccolo dan Billings memperlihatkan bahwa faktor imigrasi pada suatu negara yang memiliki populasi yang sangat padat sangat mempengaruhi laju penyebaran suatu penyakit. Piccolo membahas dinamika dan analisis kestabilan baik secara local maupun global dan effect vaksinasi terhadap model imigran [5].

Asumsi bahwa kontrol pengobatan dan kontrol terhadap penggunaan vaksinasi dapat mempengaruhi kemampuan virus dalam menginfeksi penderita menjadi dasar digunakannya metode kontrol optimal. Prinsip Maksimum Pontryagin adalah suatu metode yang dapat digunakan dalam menyelesaikan masalah kontrol optimal. Metoda ini belum dikerjakan oleh Piccolo dkk. Berdasarkan latar belakang tersebut maka pada paper ini didiskusikan masalah kontrol optimal dengan efek vaksinasi dan pengaruh faktor imigrasi, menggunakan model SIR klasik pada Piccolo[5].

\section{Model Matematika}

Dengan mengacu pada [5], beberapa asumsi yang dipergunakan dalam pembentukan model adalah populasi manusia dibagi menjadi 3 kompartemen yaitu manusia rentan (S) merupakan manusia sehat dan berpeluang untuk terinfeksi penyakit, manusia terinfeksi (I) merupakan manusia rentan yang terinfeksi suatu penyakit dan manusia sembuh $(\mathrm{R})$ merupakan manusia terinfeki penyakit yang mengalami kesembuhan. Total populasi diasumsikan tetap atau konstan. Populasi imigran dan warga negara tidak dipisahkan, dimana populasi imigran berinteraksi dengan warganegara sehingga tidak ada perbedaan. Tidak ada periode latent untuk penyakit, dimana penyakit ditularkan secara seketika melalui kontak. Tidak ada individu terinfeksi yang akan menjadi rentan kembali. Vaksinasi diberikan kepada bayi yang baru lahir dan imigran yang baru masuk. Dari asumsi-asumsi tersebut dapat dibentuk diagram skematik sebagai berikut :

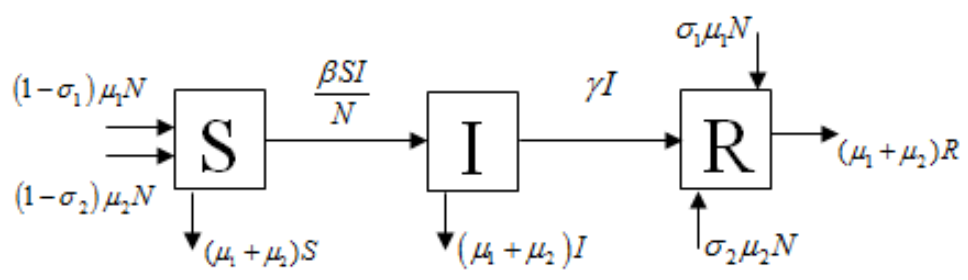

Gambar 1. Skema Penyebaran Penyakit dengan Pengaruh Vaksinasi dan Faktor Imigrasi [5]

Dengan memperhatikan asumsi dan diagram skematik pada Gambar 1 diperoleh model persamaan diferensial sebagai berikut [5]:

$$
\begin{aligned}
& \frac{d S}{d t}=\left(1-\sigma_{1}\right) \mu_{1} N+\left(1-\sigma_{2}\right) \mu_{2} N-\frac{\beta S I}{N}-\left(\mu_{1}+\mu_{2}\right) S \\
& \frac{d I}{d t}=\frac{\beta S I}{N}-\gamma I-\left(\mu_{1}+\mu_{2}\right) I \\
& \frac{d R}{d t}=\sigma_{1} \mu_{1} N+\sigma_{2} \mu_{2} N+\gamma I-\left(\mu_{1}+\mu_{2}\right) R
\end{aligned}
$$

Jumlah populasi adalah $N$, untuk menyederhanakan sistem persamaan (1) dengan melakukan normalisasi dimana proporsi banyaknya individu pada masing-masing kelompok dapat dinyatakan sebagai $\hat{s}=\frac{S}{N}, \hat{\imath}=\frac{I}{N}, \hat{r}=\frac{R}{N}$ populasi telah dinormalisasi artinya $\hat{s}+\hat{i}+\hat{r}=1$ dan didapatkan sistem persamaan baru sebagai berikut. 


$$
\begin{aligned}
& \frac{d \hat{s}}{d t}=\left(1-\sigma_{1}\right) \mu_{1}+\left(1-\sigma_{2}\right) \mu_{2}-\beta \hat{s} \hat{i}-\left(\mu_{1}+\mu_{2}\right) \hat{s} \\
& \frac{d \hat{i}}{d t}=\beta \hat{s} \hat{i}-\gamma \hat{i}-\left(\mu_{1}+\mu_{2}\right) \hat{i} \\
& \frac{d \hat{r}}{d t}=\sigma_{1} \mu_{1}+\sigma_{2} \mu_{2}+\gamma \hat{i}-\left(\mu_{1}+\mu_{2}\right) \hat{r}
\end{aligned}
$$

Penjelasan mengenai variabel dan parameter dapat dilihat pada Tabel 1 berikut ini.

Tabel 1. Parameter yang Mempengaruhi Pembentukkan Model Epidemik SIR dengan Pengaruh Vaksinasi dan Faktor Imigrasi [5]

\begin{tabular}{|c|l|}
\hline Notasi & \multicolumn{1}{|c|}{ Keterangan } \\
\hline$N$ & Jumlah populasi \\
\hline$\mu_{1}$ & Laju kelahiran warga negara (diasumsikan konstan) \\
\hline$\mu_{2}$ & Laju imigran yang masuk ke dalam populasi \\
\hline$\mu_{1}+\mu_{2}$ & Laju kematian alami (untuk warga negara dan imigran) \\
\hline$\sigma_{1}$ & $\begin{array}{l}\text { Laju sebagian warga negara yang divaksinasi saat lahir / tahun } \\
\text { (sisanya rentan) }\end{array}$ \\
\hline$\sigma_{2}$ & Laju imigran yang masuk ke dalam populasi diberi vaksin \\
\hline$\beta$ & Laju perubahan populasi dari rentan menjadi terinfeksi \\
\hline$\gamma$ & Laju perubahan populasi dari terinfeksi menjadi sembuh \\
\hline
\end{tabular}

\section{Hasil dan Pembahasan}

Pada bagian ini dibahas mengenai permasalahan kontrol optimal. Model dinamik [5] dikaji dengan memperhatikan faktor imigrasi dan pengaruh vaksinasi. Dari sistem persamaan (2) dilakukan kontrol optimal untuk pengobatan dan vaksinasi. Kontrol optimal tersebut bertujuan untuk meminimumkan jumlah populasi terinfeksi. Untuk meminimumkan jumlah individu yang terinfeksi diberikan tindakan kontrol $u_{1}(t), u_{2}(t)$ dan $u_{3}(t)$. Kontrol $u_{1}(t)$ yaitu upaya untuk mengurangi jumlah individu terinfeksi dengan melakukan pengobatan, $u_{2}(t)$ merupakan kontrol vaksinasi untuk warganegara dan $u_{3}(t)$ adalah kontrol vaksinasi untuk imigran. Sehingga persamaan (2) menjadi :

$$
\begin{aligned}
& \frac{d \hat{s}}{d t}=\left(1-\left(1+u_{2}\right) \sigma_{1}\right) \mu_{1}+\left(1-\left(1+u_{3}\right) \sigma_{2}\right) \mu_{2}-\beta \hat{s} \hat{i}-\left(\mu_{1}+\mu_{2}\right) \hat{s} \\
& \frac{d \hat{i}}{d t}=\beta \hat{s} \hat{i}-u_{1} \gamma \hat{i}-\left(\mu_{1}+\mu_{2}\right) \hat{i} \\
& \frac{d \hat{r}}{d t}=\left(1+u_{2}\right) \sigma_{1} \mu_{1}+\left(1+u_{3}\right) \sigma_{2} \mu_{2}+u_{1} \gamma \hat{i}-\left(\mu_{1}+\mu_{2}\right) \hat{r}
\end{aligned}
$$

Berikut adalah penyelesaian kontrol optimal pengobatan dengan menggunakan Prinsip Maksimum Pontryagin. Permasalahan kontrol optimal sistem dinamik terdiri dari fungsi objektif (performance index), yang dibatasi oleh sistem dinamik, nilai awal state diketahui, waktu akhir $T$ ditentukan, dan state akhir $x(T)$ bebas. Fungsi objektif untuk model (3) adalah :

$$
J=\min _{u_{1}, u_{2}, u_{3}} \int_{0}^{t_{f}}\left(A \hat{i}+C_{1} u_{1}^{2}+C_{2} u_{2}^{2}+C_{3} u_{3}^{2}\right) d t
$$


dengan kendala,

$$
\begin{aligned}
& \frac{d \hat{s}}{d t}=\left(1-\left(1+u_{2}\right) \sigma_{1}\right) \mu_{1}+\left(1-\left(1+u_{3}\right) \sigma_{2}\right) \mu_{2}-\beta \hat{s} \hat{i}-\left(\mu_{1}+\mu_{2}\right) \hat{s} \\
& \frac{d \hat{i}}{d t}=\beta \hat{s} \hat{i}-u_{1} \gamma \hat{i}-\left(\mu_{1}+\mu_{2}\right) \hat{i} \\
& \frac{d \hat{r}}{d t}=\left(1+u_{2}\right) \sigma_{1} \mu_{1}+\left(1+u_{3}\right) \sigma_{2} \mu_{2}+u_{1} \gamma \hat{i}-\left(\mu_{1}+\mu_{2}\right) \hat{r} \\
& 0 \leq t \leq t_{f} \\
& 1 \leq u_{1} \leq 2 \\
& 0 \leq u_{2} \leq 1 \\
& 0 \leq u_{3} \leq 1
\end{aligned}
$$

Dimana $t_{f}$ adalah waktu akhir, koefisien $A$ merupakan jumlah individu terinfeksi, $C_{1}$ merupakan biaya pengobatan untuk warga negara maupun imigran, $C_{2}$ merupakan biaya vaksinasi untuk warga negara dan $C_{3}$ merupakan biaya vaksinasi untuk imigran. Dengan menyelesaikan fungsi objektif tersebut akan didapatkan kontrol optimal $u_{1}^{*}, u_{2}^{*}, u_{3}^{*}$.

Dalam penyelesaian menggunakan prinsip maksimum dibutuhkan persamaan Hamiltonian yang dibentuk dari fungsional objektif ditambahkan dengan semua kendalanya yang dikalikan dengan variabel adjoint, bentuk umum dari persamaan Hamiltonian adalah sebagai berikut.

$$
H=f(x, u, t)+p g(x, u, t)
$$

dalam hal ini $p$ adalah vektor co-state dimana komponen-komponennya disebut variabelvariabel adjoint atau lebih umum disebut dengan pengali Lagrange. Kondisi optimal pada Prinsip Maksimum Pontryagin dapat dicapai dengan

$$
\frac{\partial H}{\partial u}=0 \text { dan } \dot{p}=-\frac{\partial H}{\partial x}
$$

persamaan Hamiltonian dalam masalah ini dapat ditulis sebagai berikut.

$$
\begin{aligned}
& H=A \hat{i}+C_{1} u_{1}^{2}+C_{2} u_{2}^{2}+C_{3} u_{3}^{2}+p_{1}\left(\left(1-\left(1+u_{2}\right) \sigma_{1}\right) \mu_{1}+\left(1-\left(1+u_{3}\right) \sigma_{2}\right) \mu_{2}-\beta \hat{s} \hat{i}-\left(\mu_{1}+\mu_{2}\right) \hat{s}\right) \\
& +p_{2}\left(\beta \hat{s} \hat{i}-u_{1} \gamma \hat{i}-\left(\mu_{1}+\mu_{2}\right) \hat{i}\right) \\
& +p_{3}\left(\left(1+u_{2}\right) \sigma_{1} \mu_{1}+\left(1+u_{3}\right) \sigma_{2} \mu_{2}+u_{1} \gamma \hat{i}-\left(\mu_{1}+\mu_{2}\right) \hat{r}\right)
\end{aligned}
$$

Untuk mendapat syarat perlu dari persamaan (4) dilakukan penurunan terhadap masingmasing kompartemen $S, I, R$. yaitu:

$$
\begin{aligned}
& \dot{p}_{1}=-\frac{\partial H}{\partial \hat{s}}=p_{1}\left(\beta \hat{i}+\left(\mu_{1}+\mu_{2}\right)\right)+p_{2}(-\beta \hat{i}) \\
& \dot{p}_{2}=-\frac{\partial H}{\partial \hat{i}}=-A+p_{1}(\beta \hat{s})+p_{2}\left(-\beta \hat{s}+u_{1} \gamma+\left(\mu_{1}+\mu_{2}\right)\right)+p_{3}\left(-u_{1} \gamma\right) \\
& \dot{p}_{3}=-\frac{\partial H}{\partial \hat{r}}=p_{3}\left(\mu_{1}+\mu_{2}\right)
\end{aligned}
$$

persamaan (5) adalah sistem adjoint atau sistem bayangan dari sistem (3), sistem tersebut menjelaskan sistem baru yang dihasilkan dari Prinsip Maksimum Pontryagin. Berikut teorema untuk memperoleh nilai $p_{i}, \forall i=1,2,3$ 
Teorema 1 [Pontyagin,1962] Misalkan $u^{*}(t)$ adalah sebuah vektor kontrol yang diperkenankan (admissible vector control), mentransfer titik awal $\left(x_{0}, t_{0}\right)$ ke sebuah target atau titik akhir $(x(T), T)$ dengan $x(T)$ dan $T$ tidak ditentukan secara umum. Misalkan $x^{*}(t)$ adalah sebuah trayektori yang bersesuaian dengan $u^{*}(t)$. Agar $u^{*}(t)$ optimal ada syarat perlu bahwa terdapat sebuah fungsi vektor kontinu yang tidak nol yaitu $p^{*}(t)=\left(p_{1}^{*}(t), p_{2}^{*}(t), \ldots, p_{n}^{*}(t)\right)$ dan sebuah skalar konstan $p_{0}$ sedemikian sehingga

a) $p^{*}(t)$ dan $u^{*}(t)$ adalah solusi dari sistem kanonik :

$$
\begin{aligned}
& \dot{x}^{*}(t)=\frac{\partial H}{\partial p}\left(x^{*}, p^{*}, u^{*}, t\right) \\
& \dot{p}^{*}(t)=-\frac{\partial H}{\partial x}\left(x^{*}, p^{*}, u^{*}, t\right)
\end{aligned}
$$

Dengan $H=\sum_{0}^{n} p_{i} f_{i}(x, p, u, t)=f_{0}(x, p, u, t)+\sum_{1}^{n} p_{i} f_{i}(x, p, u, t)$ adalah persamaan Hamiltonian biasa dengan $p_{0}=1$

b) $H\left(x^{*}, u^{*}, p^{*}, t\right) \geq H\left(x^{*}, u, p, t\right)$

c) Semua kondisi kendala dipenuhi.

Untuk mendapat syarat perlu dari persamaan (4) dilakukan penurunan terhadap masingmasing kompartemen yaitu

$$
\dot{p}_{1}=-\frac{\partial H}{\partial \hat{s}}, \dot{p}_{2}=-\frac{\partial H}{\partial \hat{i}}, \dot{p}_{3}=-\frac{\partial H}{\partial \hat{r}}
$$

Kemudian, kondisi optimal akan dicapai dengan cara menurunkan persamaan (4) terhadap $u_{1}$, $u_{2}$ dan $u_{3}$ sehingga didapatkan solusi sebagai berikut.

$$
\begin{array}{ll}
\frac{\partial H}{\partial u_{2}}=0 & \frac{\partial H}{\partial u_{3}}=0 \\
2 C_{2} u_{2}^{*}-\left(\sigma_{1} \mu_{1}\right)\left(p_{1}-p_{3}\right)=0 & 2 C_{3} u_{3}^{*}-\left(\sigma_{2} \mu_{2}\right)\left(p_{1}-p_{3}\right)=0 \\
u_{2}^{*}=\frac{\left(\sigma_{1} \mu_{1}\right)\left(p_{1}-p_{3}\right)}{2 C_{2}} & u_{3}^{*}=\frac{\left(\sigma_{2} \mu_{2}\right)\left(p_{1}-p_{3}\right)}{2 C_{3}}
\end{array}
$$

Dapat ditulis,

$$
u_{1}^{*}=\left\{\begin{array}{cc}
1 & \frac{\gamma i\left(p_{2}-p_{3}\right)}{2 C_{1}} \leq 1 \\
\frac{\gamma i\left(p_{2}-p_{3}\right)}{2 C_{1}} & 1<\frac{\gamma i\left(p_{2}-p_{3}\right)}{2 C_{1}}<2 \\
2 & \frac{\gamma i\left(p_{2}-p_{3}\right)}{2 C_{1}} \geq 2
\end{array}\right.
$$




$$
\begin{gathered}
u_{2}^{*}=\left\{\begin{array}{cc}
0 & \frac{\left(\sigma_{1} \mu_{1}\right)\left(p_{1}-p_{3}\right)}{2 C_{2}} \leq 0 \\
\frac{\left(\sigma_{1} \mu_{1}\right)\left(p_{1}-p_{3}\right)}{2 C_{2}} & 0<\frac{\left(\sigma_{1} \mu_{1}\right)\left(p_{1}-p_{3}\right)}{2 C_{2}}<1 \\
1 & \frac{\left(\sigma_{1} \mu_{1}\right)\left(p_{1}-p_{3}\right)}{2 C_{2}} \geq 1
\end{array}\right. \\
u_{3}^{*}=\left\{\begin{array}{cc}
\frac{\left(\sigma_{2} \mu_{2}\right)\left(p_{1}-p_{3}\right)}{2 C_{3}} \leq 0 \\
\frac{\left(\sigma_{2} \mu_{2}\right)\left(p_{1}-p_{3}\right)}{2 C_{3}} & 0<\frac{\left(\sigma_{2} \mu_{2}\right)\left(p_{1}-p_{3}\right)}{2 C_{3}}<1 \\
1 & \frac{\left(\sigma_{2} \mu_{2}\right)\left(p_{1}-p_{3}\right)}{2 C_{3}} \geq 1
\end{array}\right.
\end{gathered}
$$

Untuk lebih jelasnya, hasil analisis dari sifat-sifat kontrol optimal yang telah diperoleh diatas dapat dilihat pada simulasi numerik berikut.

\section{Analisis Numerik}

Pada bagian ini terdapat sebuah kasus, dengan data merujuk pada [6] tentang penyebaran penyakit dengan laju kelahiran $\mu_{1}=0,4$, laju imigran $\mu_{2}=0,15$, laju perubahan populasi dari rentan menjadi terinfeksi $\beta=0,8$ dan laju perubahan populasi dari terinfeksi menjadi sehat $\gamma=0,03$. Kondisi awal rasio jumlah penduduk pada kelas susceptible, infected, dan recovered masing-masing adalah 0,$8 ; 0,2 ; 0$.

Berikut adalah grafik-grafik yang memperlihatkan pengaruh vaksinasi pada masingmasing kompartemen terhadap waktu.

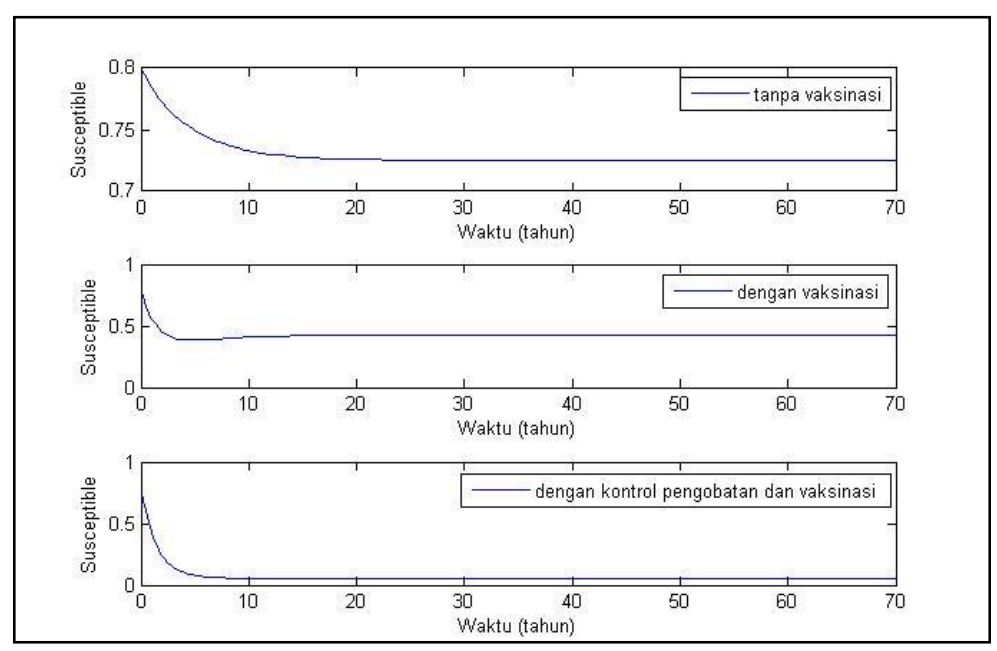

Gambar 2. Grafik Pengaruh Vaksinasi pada Individu Susceptible.

Gambar 2. memperlihatkan pengaruh vaksinasi pada individu susceptible. Terlihat bahwa setelah dilakukan pemberian vaksin, individu susceptible akan semakin berkurang. Jumlah individu susceptible akan lebih berkurang lagi setelah dilakukan kontrol pada pengobatan dan vaksinasi. 

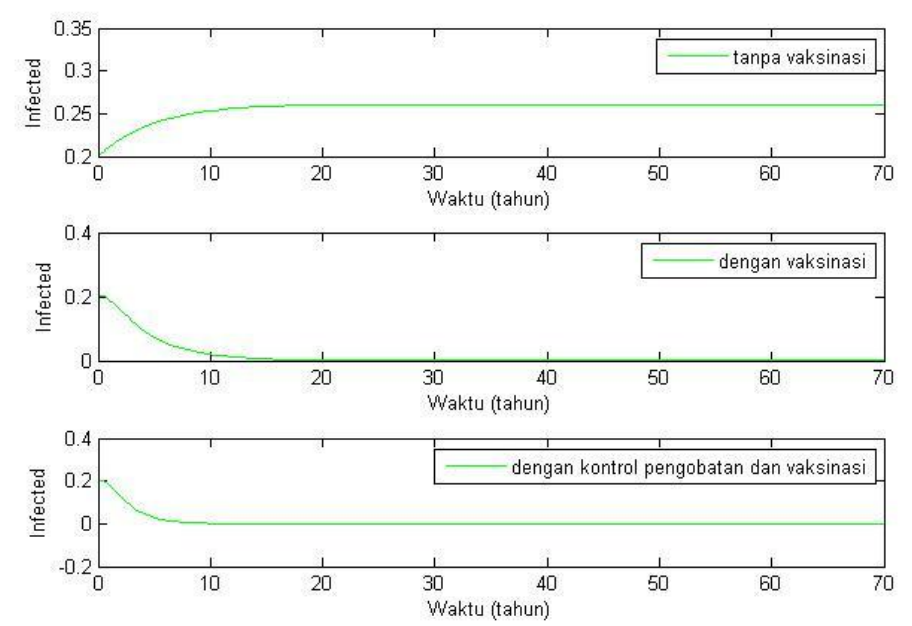

Gambar 3. Grafik Pengaruh Vaksinasi pada Individu Infected

Gambar 3 memperlihatkan pengaruh vaksinasi pada individu infected. Terlihat bahwa setelah dilakukan pemberian vaksin, individu infected akan semakin berkurang. Jumlah individu infected akan lebih berkurang lagi setelah dilakukan kontrol pada pengobatan dan vaksinasi.

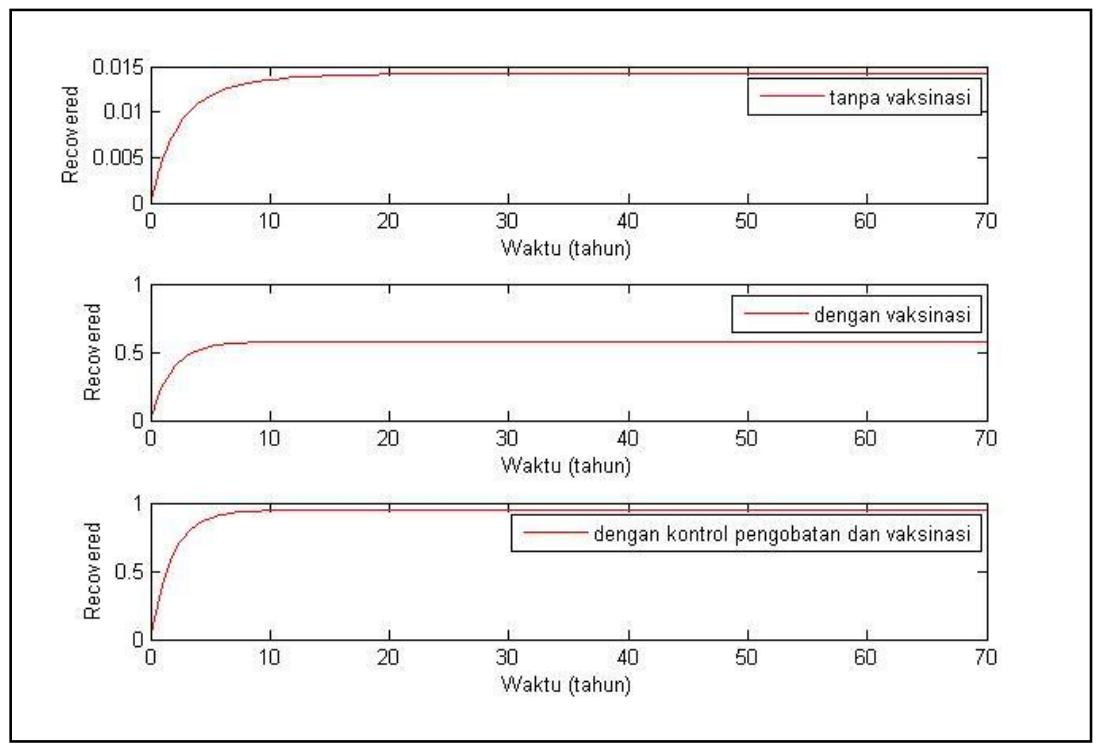

Gambar 4. Grafik Pengaruh Vaksinasi pada Individu Recovered

Gambar 4 memperlihatkan pengaruh vaksinasi pada individu recovered. Terlihat bahwa setelah dilakukan pemberian vaksin, individu recovered akan semakin bertambah. Jumlah individu recovered akan lebih bertambah lagi setelah dilakukan kontrol pada pengobatan dan vaksinasi. Pada waktu tertentu, proporsi individu susceptible, infected dan recovered tidak mengalami perubahan sehingga sistem berada pada kondisi setimbang. Dengan menggunakan Maple 12, kriteria kestabilan di titik kesetimbangan dapat digambarkan dengan trayektori pada bidang fase Susceptible-Infected sebagai berikut. 


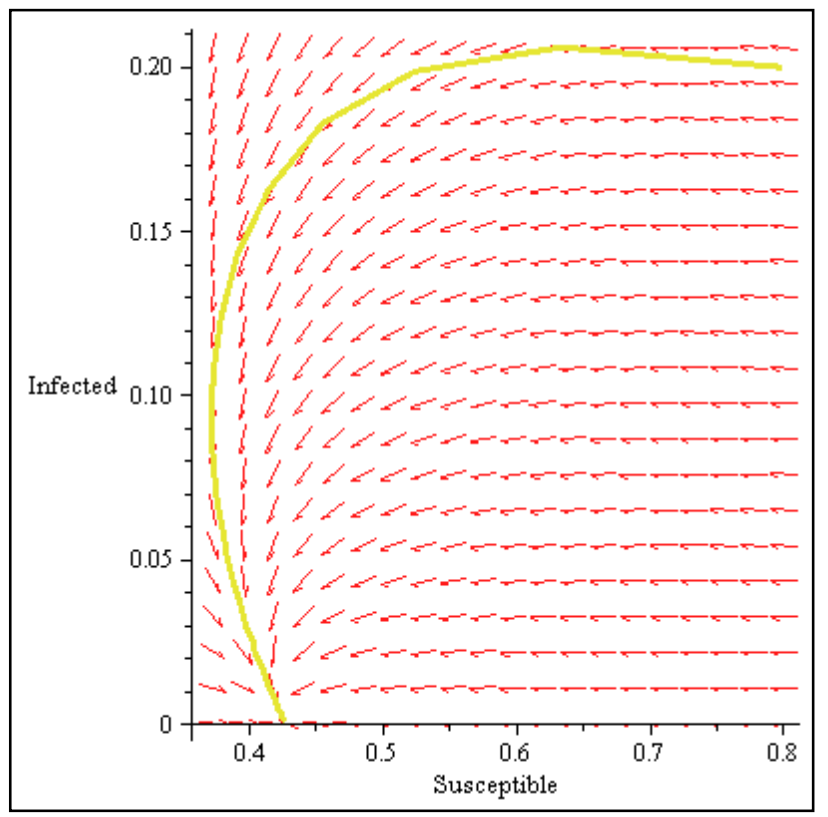

Gambar 5. Trayektori pada Bidang Fase Susceptible-Infected

Gambar 5 menunjukkan bahwa semua trayektori menuju ke arah titik tetap nonendemik $(0,427 ; 0)$. Oleh karena itu, titik tetap non-endemik tersebut bersifat stabil asimtotik. Bukti secara analisis untuk kestabilan secara local dan global dapat dilihat pada [5].

\section{Kesimpulan}

Dengan Prinsip Maksimum Pontryagin didapatkan solusi kontrol optimal pada model epidemik SIR, sehingga kontrol pada pemberian pengobatan dan vaksinasi berpengaruh pada berkurangnya individu rentan dan terinfeksi sehingga akan meningkatkan jumlah individu yang sehat. Hasil simulasi memperlihatkan keefektifan pengendalian dengan kontrol pengobatan dan vaksinasi dapat mengurangi populasi yang terinfeksi sehingga penyebaran penyakit dapat dicegah.

\section{Ucapan TerimaKasih}

Sebagian dari penelitian ini dibiayai oleh Hibah Penelitian Ungulan Perguruan Tinggi dengan Nomor : 393/UN6.R/PL/2015.

\section{Daftar Pustaka}

[1] F. Brauer and P. van den Driessche., 2001, Models for transmission of disease with immigrantion of infectives, Mathematical Biosciences, vol 171, no. 2, pp. 143-154.

[2] D. Chemtob and Z. Grossman., 2004, Epidemiology of adult and adolescent HIV nfection in Israel: a country of immigration, International Journal of STD and AIDS, vol. 15, no. 10, pp. 691-696.

[3] L. R. Krilov, 2004, Emerging infectious disease issues in international adoptions: severe acute respiratory syndrome (SARS), avian influenza and measles, Current Opinion in Infectious Diseases, vol. 17, no. 5, pp. 391-395.

[4] E. Shim., Z. Feng., M. Martcheva, and C. Castillo-Chavez., 2006, An age-structured epidemic model of rotavirus with vaccination, Tech. Rep. 2, Statistical and Applied Mathematical Sciences Institute.

[5] Piccolo, C. III and Billings, L., 2005., The Effect of Vaccinations in an Immigrant Model, Mathematical and Computer Modeling, no. 42, 291-299.

[6] Makinde, O. D. 2006., Modelling Transmission Dynamics of Childhood Diseases in the Presence of a Preventive Vaccine: Application of the Adomian Decomposition Technique, Proceedings of an international Workshop held at Rockefeller Foundations Bellagio Conference Center, Milan. 